\title{
Analisis Pengukuran Kualitas Website Terhadap Kepuasan Pengguna Berdasarkan Webqual 4.0
}

\author{
Rizky Esa Riyanto ${ }^{1}$, Otong Saeful Bachri* ${ }^{* 2}$ \\ ${ }^{1}$ Teknik Informatika STIKOM Poltek Cirebon \\ ${ }^{2}$ Teknik Informatika Universitas Muhadi Setiabudi Brebes \\ e-mail corresponden*: ${ }^{2}$ otong.sb@ umus.ac.id
}

\begin{abstract}
Abstrak
Website merupakan pasar online yang berkembang secara pesat dan merubah pola bisnis dengan menggunakan internet sebagai alat komunikasi. Ebill Tour Organizer adalah salah satu perusahaan travel di bidang jasa yang menjadikan Website sebagai salah satu sarana promosi perusahaan. Sebagai salah satu perusahaan travel, perlu dilakukan evaluasi untuk menilai apa yang dapat mempengaruhi kepuasan pelanggan dalam mengakses Website tersebut. Untuk menilai kepuasan pelanggan, kualitas dari layanan yang diberikan menjadi fokus utama yang sangat mempengaruhi kepuasan pelanggan. Untuk mengukur kepuasan pelanggan diperlukan metode dan alat ukur yang akurat dan sesuai, sepertiWebQual 4.0. Setelah dilakukan pengujian dari hasil penilaian pengguna Ebill Tour Organizer menggunakan WebQual 4.0, perlu dilakukan analisis data menggunakan teknik analisis regresi linier. Hasil dari penelitian ini menunjukkan bahwa secara signifikan, kualitas Website yang terdiri dari usability, information quality dan service interaction quality mempengaruhi kepuasan pelanggan Ebill Tour Organizer. Terlihat dari hubungan antar variabel bebas memberikan hubungan positif terhadap variabel kepuasan pelanggan.
\end{abstract}

Kata kunci-WebQual, pengukuran kualitas, kepuasan pengguna

\begin{abstract}
Website is an online market that is growing rapidly and changing business patterns by using the internet as a communication tool. Ebill Tour Organizer is one of the travel companies in the field of services that makes the Website as one of the means of corporate promotion. As a travel company, an evaluation is needed to assess what can affect customer satisfaction in accessing the Website. To assess customer satisfaction, the quality of services provided is the main focus that greatly influences customer satisfaction. Measuring customer satisfaction requires accurate and appropriate methods and measuring instruments, such as WebQual 4.0. After testing the results of the assessment of Ebill Tour Organizer users using WebQual 4.0, it is necessary to analyze the data using linear regression analysis techniques. The results of this study indicate that significantly, the quality of the Website consisting of usability, information quality and service interaction quality affects customer satisfaction Ebill Tour Organizer. Seen from the relationship between independent variables provides a positive relationship to the variable customer satisfaction.
\end{abstract}

Keywords - WebQual, quality measurement, user satisfaction

\section{PENDAHULUAN}

Berkembangnya internet di Indonesia, telah sedikit merubah budaya Indonesia dari cara yang tradisional menjadi lebih modern, salah satunya mengunakan internet dalam kehidupan sehari - hari. Perkembangan internet yang sangat pesat semakin mempermudah akses informasi

Submitted: 23 April 2019, Accepted: 29 April 2019, Published: Mei 2019

ISSN: 2685-4902 (online), Website: http://jurnal.umus.ac.id/index.php/intech 
dalam berbagai bidang, baik di bidang jasa ataupun produk. PT. Ebill Tour Organizer merupakan salah satu perusahaan travel yang memanfaatkan Website yang beralamat di www.ebill-tour.com sebagai sarana yang mudah bagi pelanggan dalam memilih paket wisata. Studi ini dilakukan untuk mengevaluasi kualitas layanan Website berdasarkan persepsi pengguna akhir yang diukur menggunakan metode WebQual 4.0, menganalisis tingkat kepuasan pengguna terhadap layanan Website, dan mengetahui faktor-faktor kinerja penting apa saja yang harus ditingkatkan dalam memenuhi kepuasan para pengguna Website tersebut. Teknik analisis yang digunakan adalah analisis statistik deskriptif melalui uji validitas, uji reliabilitas, WebQual Index (WQI), Importance Performance Analysis (IPA), dan Customer Satisfaction Index (CSI). Pengolahan data dibantu dengan Microsoft Excel dan perangkat lunak IBM SPSS (Statistic Product and Service Solution) versi 22.0. Penelitian ini bertujuan untuk mengukur kepuasan pengguna yang belum tersedia pada website lama seperti contoh ulasan, forum diskusi, layanan informasi interaktif baik call centre ataupun pemesanan/booking paket wisata online pelanggan, belum lagi berapa jumlah pengunjung pada website tersebut juga masih belum terlihat.

Kualitas terhadap suatu web (WebQual) akan mempengaruhi keputusan pembelian pada suatu website ecommerce, dimana variabel website quality berpengaruh signifikan terhadap variabel keputusan pembelian, dimana variabel website quality dapat menjelaskan variabel keputusan pembelian sebesar 40,5\% sedangkan 59,5\% lainnya dijelaskan oleh variabel lain[1]. WebQual juga pernah digunakan untuk melakukan pengukuran terhadap kualitas layanan suatu website Kementrian Kominfo, dimana dari 19 pertanyaan yang membentuk dimensi webqual ada 4 butir pertanyaan yang tidak valid yaitu kemudahan dalam pengoperasian website kominfo, interaksi antara website kominfo dengan pengguna, kemudahan penggunaan, dan informasi yang disediakan mudah dimengerti. Sedangkan dimensi kegunaan dan kualitas interaksi yang dinilai tidak berpengaruh terhadap kepuasan penggunaan website[2]. Selain itu persamaan regresi juga dapat digunakan untuk menunjukkan variabel independen berdasarkan dimensi webqual (usability, kualitas informasi dan kualitas informasi). Menurutnya kualitas suatu website dikatakan sangat bagus apabila bernilai sebesar 117,275 dimana hal ini akan memungkinkan nilai dari keseluruhan dimensi website bernilai 5, sedangkan kualitas suatu website dikatakan tidak bagus apabila bernilai 23,453 yang memungkinkan setiap item dikeseluruhan dimensi bernilai 1. Dan website pemda ogan ilir memiliki nilai diantara 52 dan 90 dengan rata-rata 73,3375 yang berarti bahwa website pemda ogan ilir bisa dikatakan cukup bagus[3]. Webqual juga dapat digunakan untuk melakukan evaluasi terhadap kualitas website suatu universitas, melalui pendekatan IPA (Importance Performance Analysis) melalui pendekatan survey untuk mengetahui gap antara kepentingan dan kinerja. Menurut hasil uji validitas dan realibilitas menunjukkan keseluruhan item kuisioner tersebut valid dan realible, dimana dari 22 item yang dianalisis dengan model IPA dikelompokkan kedalam kuadran I (3 item), kuadran II (9 item), kuadran III (7 item) dan kuadran IV (3 item). Dimana item yang dianggap penting adalah kemudahan dalam berkomunikasi melalui web yang terdapat pada kuadran I. Selain itu hasil analisis juga menunjukkan adanya hubungan yang sangat kuat antara variabel independen dan dependen[4].

Dalam penelitian ini, peneliti menggunakan webqual karena webqual dapat digunakan untuk menganalisis kualitas beberapa website, baik website internal (career centre, staffsite, studentsite, central library, internal information system dan lain-lain) maupun website eksternal website seperti maskapai penerbangan, e-banking, jual beli online dan lainnya[5]

\section{METODE PENELITIAN}

\section{Kerangka berfikir}

Berdasarkan tujuan dan kegunaan dari penelitian ini, maka jenis penelitian yang penulis gunakan dalam penelitian ini adalah deskripstif verivikatif yang akan melihat sejauh mana 2 variabel akan saling berhubungan. Dalam penelitian ini 2 variabel yang terlibat adalah varibel 
bebas yaitu website quality melalui webqual, dan variabel terikat yaitu variabel keputusan pembelian. Adapun kerangka pemikiran dari penelitian ini terdapat pada Gambar 1. Kerangka pemikiran pada Gambar 1 berfungsi untuk menguraikan dimensi kualitas pada Website berdasarkan dimensi Webqual yang menjadi fokus dari penelitian ini. Dimensi dalam Webqual merupakan instrumen yang digunakan untuk menilai kualitas suatu Website dari persepsi pengguna akhir. Kualitas dapat dicerminkan dari perbandingan antara nilai kepentingan (importance) yang diharapkan dengan kinerja (performance) yang dirasakan secara nyata. Tingkat kepuasan dapat dilihat dari nilai kesenjangan (gap) antara kedua perspektif tersebut.

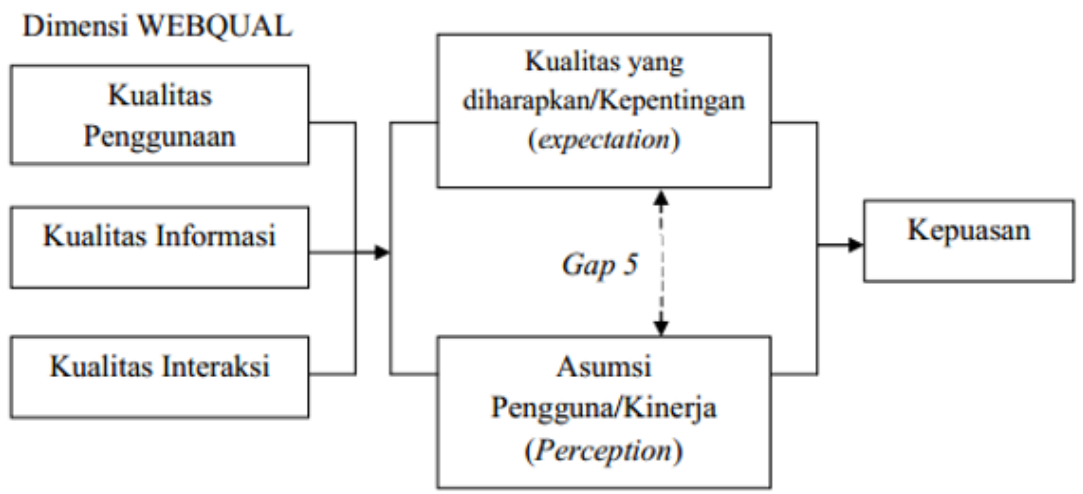

Gambar 1. Kerangka berfikir

\section{Teori webqual}

Menurut teori WebQual, terdapat tiga dimensi inti yang mewakili kualitas suatu website, yaitu usability, information quality dan service interaction quality[6]. Kualitas inti WebQual berasal dari dukungan dari berbagai literatur primer dan sekunder yang mengacu pada penelitian dari tiga bidang utama yaitu:[6]

1. Information quality yang berasal dari penelitian mengenai sistem informasi. Pertanyaanpertanyaan yang dikembangkan di bagian ini dibangun berdasarkan literatur yang berfokus pada kualitas informasi, data dan sistem.

2. Service Interaction Quality yang berasal dari penelitian mengenai kualitas layanan marketing, e-commerce, dan sistem informasi

3. Usability yang berasal dari penelitian dalam bidang Human Computer Interaction (HCI) atau interaksi manusia dan komputer dan web usability.

Dalam penelitian ini user interface quality merupakan dimensi baru yang ditambahkan kedalam dimensi asli webqual 4.0 untuk mengetahui kualitas antar muka website yang berkaitan dengan daya tarik (attractiveness) visual dari user interface.

Webqual sebenarnya metamorfosis dari beberapa versi, untuk versi pertama dari instrumen webqual (webqual 1.0) dikembangkan sebagai bagian dari hasil lokakarya yang diselenggarakan dengan melibatkan para siswa yang diminta untuk mempertimbangkan kualitas website sekolah[7]. Kualitas yang dikembangkan dalam webqual 1.0 membentuk titik awal untuk menilai kualitas informasi dari suatu website di webqual 2.0 namun demikian dalam penerapan webqual pada website berjenis B2C terlihat jelas bahwa bahwa perspesktif interaksi kualitas tidak terwakili dengan baik dalam webqual 1.0[7]. Terkait dengan kualitas layanan terutama ServQual digunakan untuk meningkatkan aspek kualitas informasi dari webqual dengan kualitas interaksi. Pengembangan webqual 2.0 memerlukan beberapa perubahan signifikan pada instrumen webqual 1.0 yang berhasil mengidentifikasi pertanyaan mubazir dan tumpang tindih[7]. Demikian juga untuk webqual 2.0 yang menekankan kualitas interaksi menghilangkan beberapa kualitas informasi dari webqual 1.0

\section{HASIL DAN PEMBAHASAN}

1. Uji reliabilitas 
Reliabilitas merupakan kemampuan untuk konsisten dalam melakukan pelayanan yang dijanjikan[8]. Hasil uji reliabilitas dapat dilihat pada Tabel 1.

\begin{tabular}{|c|c|c|c|}
\hline Variabel & Item & $\begin{array}{c}\text { Cronbach's } \\
\text { alpha }\end{array}$ & Keterangan \\
\hline \multirow{11}{*}{ Usability } & U1A & \multirow{11}{*}{0,925} & \multirow{11}{*}{ Reliable } \\
\hline & U1B & & \\
\hline & $\mathrm{U} 1 \mathrm{C}$ & & \\
\hline & U1D & & \\
\hline & U2A & & \\
\hline & U2B & & \\
\hline & U2C & & \\
\hline & U3A & & \\
\hline & U3B & & \\
\hline & IQ1A & & \\
\hline & IQ1B & & \\
\hline \multirow{6}{*}{$\begin{array}{c}\text { Information } \\
\text { quality }\end{array}$} & IQ2A & \multirow{6}{*}{0,92} & \multirow{6}{*}{ Reliable } \\
\hline & IQ2B & & \\
\hline & IQ3A & & \\
\hline & IQ3B & & \\
\hline & SQ1 & & \\
\hline & SQ2 & & \\
\hline \multirow{5}{*}{$\begin{array}{c}\text { Service } \\
\text { interaction } \\
\text { quality }\end{array}$} & $\mathrm{A}$ & \multirow{5}{*}{0,935} & \multirow{5}{*}{ Reliable } \\
\hline & SQ2B & & \\
\hline & SQ3 & & \\
\hline & A & & \\
\hline & $\frac{\text { SQ3B }}{\text { SQ3C }}$ & & \\
\hline
\end{tabular}

2. Uji validitas

Uji validitas bertujuan untuk mengukur tingkat valid tidaknya suatu kuisioner, dimana suatu kuesioner dikatakan valid apabila pernyataan pada kuesioner mampu menjelaskan sesuatu yang diukur oleh kuesioner tersebut. Hasil pengujian validitas terdapat pada Tabel 2.

Tabel 2. Hasil uji validitas

\begin{tabular}{|c|c|c|c|}
\hline Variabel & $\begin{array}{c}\text { Butir } \\
\text { pernyataan }\end{array}$ & $\begin{array}{c}\text { Nilai } \mathbf{r} \\
\text { hitung }\end{array}$ & Keterangan \\
\hline \multirow{4}{*}{} & U1A & 0,795 & Valid \\
\cline { 2 - 4 } & U1B & 0,783 & Valid \\
\cline { 2 - 4 } & U1C & 0,839 & Valid \\
\cline { 2 - 4 } & U1D & 0,683 & Valid \\
\cline { 2 - 4 } & U2A & 0,74 & Valid \\
\cline { 2 - 4 } & U2B & 0,8 & Valid \\
\cline { 2 - 4 } & U2C & 0,861 & Valid \\
\cline { 2 - 4 } & U3A & 0,89 & Valid \\
\cline { 2 - 4 } & U3B & 0,807 & Valid \\
\cline { 2 - 4 } & IQ1A & 0,9 & Valid \\
\cline { 2 - 4 } & IQ1B & 0,718 & Valid \\
\hline \multirow{5}{*}{ quality } & IQ2A & 0,898 & Valid \\
\cline { 2 - 4 } & IQ2B & 0,887 & Valid \\
\cline { 2 - 4 } & IQ3A & 0,823 & Valid \\
\cline { 2 - 4 } & IQ3B & 0,837 & Valid \\
\cline { 2 - 4 } & SQ1A & 0,677 & Valid \\
\cline { 2 - 4 } & SQ1B & 0,817 & Valid \\
\hline Service & SQ2A & 0,934 & Valid \\
\hline
\end{tabular}




\begin{tabular}{|c|c|c|c|}
\hline interaction & SQ2B & 0,873 & Valid \\
\cline { 2 - 4 } quality & SQ3A & 0,846 & Valid \\
\cline { 2 - 4 } & SQ3B & 0,934 & Valid \\
\cline { 2 - 4 } & SQ3C & 0,888 & Valid \\
\hline
\end{tabular}

3. Pengumpula data

Penyajian data yang diberikan berdasarkan hasil dari penyebaran kuesioner kepada 109 orang responden dengan 104 responden yang valid. Hasil yang didapatkan bersifat kuantitatif. Proses pengumpulan data ini dilakukan dengan menyebarkan kuesioner berbentuk online kepada pelanggan Ebill Tour. Demografi profil responden dapat dilihat pada Tabel 3.

Tabel 3. Demografi responden

\begin{tabular}{|c|c|c|}
\hline Ukuran sample & Jumlah & Persentase (\%) \\
\hline \multicolumn{3}{|l|}{ Umur } \\
\hline 17 & 2 & 1,83 \\
\hline 18 & 10 & 9,17 \\
\hline 19 & 17 & 15,60 \\
\hline 20 & 24 & 22,02 \\
\hline 21 & 19 & 17,43 \\
\hline 22 & 30 & 27,52 \\
\hline 23 & 7 & 6,42 \\
\hline Total & 109 & 100 \\
\hline \multicolumn{3}{|l|}{ Jenis kelamin } \\
\hline Laki-laki & 64 & 58,72 \\
\hline Perempuan & 45 & 41,28 \\
\hline Total & 109 & 100 \\
\hline \multicolumn{3}{|l|}{ Pendapatan perbulan } \\
\hline$<\mathrm{Rp} .1 \mathrm{jt}$ & 65 & 59,63 \\
\hline Rp. 1jt - Rp. 2Jt & 25 & 22,94 \\
\hline Rp. 2Jt - Rp. 3Jt & 10 & 9,17 \\
\hline Rp. 3Jt - Rp. 4Jt & 2 & 1,83 \\
\hline$>$ Rp. $4 \mathrm{Jt}$ & 7 & 6,42 \\
\hline Total & 109 & 100 \\
\hline
\end{tabular}

4. Uji mising data dan outlier

Dari hasil pengujian missing data pada 109 responden tidak ditemukan. Untuk data outlier, terdapat 5 sampel data. Sehingga data yang dilakukan analisis sejumlah 109 data.

5. Uji multikolinearitas

Pada penelitian ini, pengujian multikolinearitas bertujuan untuk menguji apakah model regresi yang digunakan terdapat korelasi antar variabel bebas. Model regresi yang baik seharusnya tidak terdapat korelasi antar variabel bebas[9]. Hasil pengujian ini dapat dilihat pada Tabel 4

Tabel 4. Hasil multikolinearitas

\begin{tabular}{|l|c|c|}
\hline \multicolumn{1}{|c|}{ Variabel } & Tolerance & Vif \\
\hline Usability & 0,254 & 3,939 \\
\hline Information quality & 0,206 & 4,863 \\
\hline Service interaction & 0,404 & 2,477 \\
\hline
\end{tabular}

6. Uji autokorelasi

Model regresi yang baik mensyaratkan tidak adanya masalah autokorelasi. Untuk mendeteksi ada tidaknya autokorelasi umumnya dilakukan dengan menggunakan uji Durbon-Watson[10] 
Tujuan dari pengujian ini ialah untuk mengetahui apakah pada sebuah model regresi linier muncul korelasi antar residual atau pengganggu pada periode $t$ dengan kesalahan pada periode sebelumnya (t-1). Hasil pengujian dapat dilihat pada Table 5.

Tabel 5 Hasil uji autokorelasi

\begin{tabular}{|l|c|c|c|c|c|}
\hline Model & $\mathbf{R}$ & R square & $\begin{array}{c}\text { Adjusted R } \\
\text { square }\end{array}$ & $\begin{array}{c}\text { Std. Error of } \\
\text { the estimate }\end{array}$ & $\begin{array}{c}\text { Durbin } \\
\text { watson }\end{array}$ \\
\hline 1 & $0,929^{\mathrm{a}}$ & 0,736 & 0,730 & 2685,433 & 2,067 \\
\hline
\end{tabular}

Dari tabel menunjukan bahwa nilai DW hitung sebesar 2,067 lebih besar dari nilai $\mathrm{d}_{\mathrm{u}}$ yaitu 1,7402 dan nilai DW hitung kurang dari $4-1,7402$ yaitu sebesar 2,2598. Dari pernyataan diatas dapat disimpulkan bahwa model regresi linier yang digunakan pada penelitian ini tidak mengandung autokorelasi.

7. Uji herterokedastisitas

Pengujian ini bertujuan untuk mengetahui sebaran antara residual dengan nilai prediksi variabel terikat yang sudah distandarisasi. Apabila sebaran titik tidak membantu pola/alur tertentu, maka dapat disimpulkan tidak ada heteroskedastisitas atau tidak terjadi homoskedastisitas. Hasil pengujian dapat dilihat pada Gambar 2.

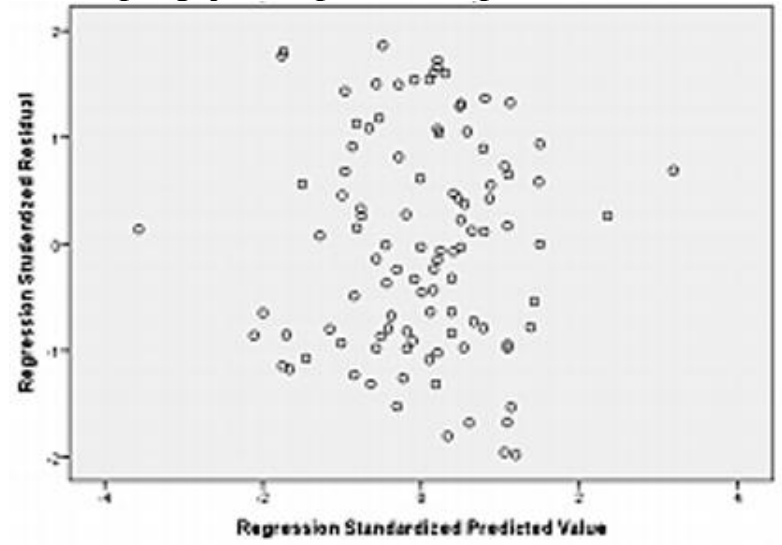

Gambar 2. Uji heterokedastisitas

8. Uji normalitas

Uji normalitas dilakukan untuk mengetahui apakah pada model regresi, residual mempunyai distribusi normal. Apabila data menyebar pada sekitar garis dan mengikuti arah garis diagonal maka model regresi memenuhi asumsi normalitas.

9. Uji keterandalan model (uji f)

Uji F bertujuan untuk mengetahuihubungan antara variabel bebas dan variable terikat.

10. Uji T

Tujuan dari uji t atau yang biasa disebut uji koefisien regresi adalah untuk menguji apakah parameter (koefisien regresi dan konstanta) yang diprediksi untuk memperkirakan persamaan/model regresi linier berganda sudah merupakan parameter yang sesuai atau tidak.

Adapun hasil dari tabel diatas dapat dijabarkan sebagai berikut:

a. Hipotesis 1

Menyatakan bahwa variabel usability memiliki statistik uji t sebesar 0,009. Apabila nilai signifikansi lebih kecil dari $\alpha(0,05)$, dapat disimpulkan bahwa $\mathrm{H} 0$ ditolak sehingga dapat dikatakan bahwa variabel usability berpengaruh secara signifikan terhadap kepuasan pengguna (user satisfcation). 
b. Hipotesis 2

Menyatakan bahwa variabel information quality memiliki statistik uji t sebesar 0,006. Apabila nilai signifikansi lebih kecil dari $\alpha(0,05)$, dapat disimpulkan bahwa H0 ditolak sehingga dapat dikatakan bahwa variabel information quality berpengaruh secara signifikan terhadap kepuasan pengguna (user satisfcation).

c. Hipotesis 3

Menyatakan bahwa variabel service interaction quality memiliki statistik uji t sebesar 0,045.Apabila nilai signifikansi lebih besar dari $\alpha(0,05)$, dapat disimpulkan bahwa $\mathrm{HO}$ ditolak sehingga dapat dikatakan bahwa variabel service interaction quality berpengaruh secara signifikan terhadap kepuasan pengguna (user satisfcation)

11. Koefisien determinasi

Koefisien determinasi atau $\mathrm{R}_{2}$ dilakukan untuk mengetahui adanya hubungan yang sempurna atau tidak yang terlihat pada perubahan variabel bebas apakah akan diikuti oleh variabel terikat pada proporsi yang sama. Dari hasil tersebut dapat disimpulkan bahwa variabel bebas (usability, information quality dan service interaction quality) dapat menjelaskan variabel terikat (kepuasan pengguna) sebesar 73,6\%, sedangkan sisanya yaitu 26,4\% dijelaskan oleh faktor lainnya yang tidak ada pada model regresi linier.

12. Analisis regresi linier berganda

Dari tabel diatas dapat diperoleh regresi linier berganda sebagai berikut ini:

$$
\mathrm{y}=-4,104+5,982 X+7,024 X+1,992 X+e(2)
$$

dimana Interpretasi model regresi diatas adalah sebagai berikut:

a. $\mathrm{B} 0=-4,104$. Koefisien regresi ini menunjukkan bahwa tanpa ada pengaruh dari variabel bebas kepada variabel terikat, maka skor total dari variabel terikat sudah meningkat (variabel kepuasan pengguna sudah menurut atau dianggap belum ada).

b. Variabel usability $(\beta 1=3,964)$

Setelah hasil tersebut dibandingkan, maka nilai signifikansi usability kurang dari 0,05 $(0,009<0,05)$. Menurut hasil perhitungan dengan uji signifikansi parsial didapatkan nilai t sebesar 3,964. Dari nilai Ttabel untuk nilai $\mathrm{df}=100$ sebesar 1,98, dibandingkan dengan Thitung sehingga didapatkan hasil bahwa Thitung > Ttabel $(3,964>1,98)$. Dari hasil perbandingan tersebut, dapat disimpulkan bahwa variabel usability menolak $\mathrm{HO}$ yang artinya variabel usability memiliki pengaruh yang signifikan serta memberikan hubungan positif terhadap kepuasan pelanggan.

c. Variabel information quality $(\mathrm{B} 2=7,024)$

Setelah hasil tersebut dibandingkan, maka nilai signifikansi variabel information quality kurang dari $0,05(0,006<0,05)$. Menurut hasil perhitungan dengan uji signifikansi parsial didapatkan nilai t sebesar 1,982. Kemudian nilai Ttabel dibandingkan dengan Thitung sehingga didapatkan hasil bahwa Thitung > Ttabel $(1,982>1,98)$. Dari hasil perbandingan tersebut, dapat disimpulkan bahwa variabel information quality menolak HO yang artinya variabel information quality memiliki pengaruh yang signifikan serta memberikan hubungan positif terhadap kepuasan pelanggan.

d. Variabel service interaction quality $(\mathrm{B} 3=1,992)$ Setelah hasil tersebut dibandingkan dengan syarat signifikansi yang harus kurang dari 0,05 maka nilai signifikansi variabel service interaction quality kurang dari $0,05(0,045<0,05)$. Menurut hasil perhitungan dengan uji signifikansi parsial didapatkan nilai t sebesar 1,982. Kemudian nilai Ttabel dibandingkan dengan Thitung sehingga didapatkan hasil bahwa Thitung > Ttabel $(2,743$ $>1,98$ ). Dari hasil perbandingan tersebut, dapat disimpulkan bahwa variabel service interaction quality menolak $\mathrm{H} 0$ yang artinya variabel service interaction quality memiliki pengaruh yang signifikan serta memberikan hubungan positif terhadap kepuasan pelanggan. 


\section{KESIMPULAN}

Berdasarkana analisis deskriptif yang telah dilakukan, harapan pengguna atas kualitas Website Ebill Tour sangat tinggi atau pengguna menganggap bahwa kualitas yang diharapkan atas kualitas Website termasuk dalam kategori sangat penting. Selain itu kinerja kualitas Website yang dirasakan pengguna ternyata cukup rendah atau pengguna menganggap bahwa kualitas yang dirasakan atas kualitas Website Ebill Tour termasuk dalam kategori cukup baik. Berbeda halnya dengan pengukuran tingkat kepuasan yang diukur melalui kualitas Website yang dirasakan pada Website Ebill Tour, namun hasilnya masih sangat rendah dibandingkan dengan harapan pengguna. Jadi, pengguna Website belum merasa puas atas kualitas yang diberikan.

\section{DAFTAR PUSTAKA}

[1] Sastika, Widya, 2016, "Analisis Pengaruh Kualitas Website (WebQual 4.0) Terhadap Keputusan Pembelian Pada Website E-Commerce Traveloka (Studi Kasus: Pengguna Traveloka di Kota Bandung Tahun 20015”, Seminar Nasional Teknologi Informasi dan Komunikasi $2016 \quad$ (SENTIKA 2016), Available https://fti.uajy.ac.id/sentika/publikasi/makalah/2016/10.pdf

[2] Sanjaya, Iman., 2012, "Pengukuran Kualitas Layanan Website Kementrian Kominfo Dengan Menggunakan Metode Webqual 4.0", Jurnal Penelitian IPTEK-KOM Volume $14 \quad$ Nomor $\quad 1 \quad$ Juni, Available https://s3.amazonaws.com/academia.edu.documents/34210796/1.PENGUKURANKUALITAS-LAYANAN-WEBSITE-KEMENTERIAN-KOMINFO-DENGANMENGGUNAKAN-METODE-WEBQUAL-4.0.pdf?response-contentdisposition=inline\%3B\%20filename\%3DJurnal_Penelitian_IPTEKKOM_PENGUKURAN_K.pdf\&X-Amz-Algorithm=AWS4-HMAC-SHA256\&X-AmzCredential=AKIAIWOWYYGZ2Y53UL3A\%2F20190722\%2Fus-east1\%2Fs3\%2Faws4_request $\& X-A m z-D a t e=20190722 T 071632 Z \& X-A m z-$

Expires $=3600 \& X-A m z-S i g n e d H e a d e r s=h o s t \& X-A m z-$

Signature $=c 72 b 706 b d 4 e 7 f 3837 b 4431 f 2 f 291158090 \mathrm{e} 1338535 \mathrm{c} 87 \mathrm{~b} 63 \mathrm{a} 279 \mathrm{fc} 36 \mathrm{f} 7 \mathrm{c} 455 \mathrm{c} 5$

[3] Irawan, Candra., 2012, "Evaluasi Kualitas Website Pemerintah Daerah Dengan Menggunakan Webqual (Studi Kasus Pada Kabupaten Ogan Ilir)", Jurnal Sistem Informasi (JSI) Volume 4 No 2 Oktober 2012 ISSN: 2085-1588 ISSN Online : 2355 4614, Available : https://ejournal.unsri.ac.id/index.php/jsi/article/view/1272/440

[4] Napitupulu, D.B., 2016, "Evaluasi Kualitas Website Universitas XYZ Dengan Pendekatan Webqual", Buletin Pos dan Telekomunikasi Vol 14 No 1 p:51-64, Available : https://www.online.bpostel.com/index.php/bpostel/article/view/140105/185

[5] Setyawa, H.B., Susilo, T.H., Apritasari, F., 2017, "Pengukuran Kualitas Website Laboratorium Komputer STIKOM Surabaya Menggunakan Metode Webqual 4.0", JSIKA Volume 6 Nomor 4 ISSN : 2338 137X, Available : http://jurnal.stikom.edu/index.php/jsika/article/view/1768/1208

[6] Arifin, S.R., Nugroho, Eko., Hantono, B.S., 2015, "Analisis Kualitas Layanan Website Universitas Hasanudin Dengan Metode WebQual 4.0 Modifikasi”, Teknomatika Volume 8 Nomor 1 Juli 2015 ISSN : 1979-7656, Available : http://teknomatika.stmikayani.ac.id/wp-content/uploads/2015/11/08.-Suci-RamadhaniArifin-Eko-Nugroho-Bimo-Sunarfri-Hantono-Analisis-Kualitas-Layanan-WebsiteUniversitas-Hasanuddin-dengan-Metode-WebQual-4.0-Modifikasi.pdf

[7] Setiyorini, Agustin., 2016, "Analisa Pengukuran Kualitas Layanan Website Fakultas Teknik Universitas Janabadra Menggunakan Metode Webqual", Jurnal Informasi Interaktif Volume 1 Nomor 1 Mei 2016, Available : http://ejournal.janabadra.ac.id/index.php/informasiinteraktif/article/view/344/252 
[8] Hermanto, A., Supangat., Mandita, F., 2017, "Evaluasi Usabilitas Layanan Sistem Informasi Akademik Berdasarkan Kombinasi Servqual dan WebQual", Journal of Information Systems Engineering and Business Intelligence Volume 3 Nomor 1 April 2017, Available : https://e-journal.unair.ac.id/JISEBI/article/view/3607/2789

[9] Monalisa, Siti., 2016, "Analisis Kualitas Layanan Website Terhadap Kepausan Mahasiswa dengan Penerapan Metode WebQual (Studi Kasus : UIN Suska Riau)", Jurnal Sains, Teknologi dan Industri Volume 13 Nomor 2 Juni, Available : http://ejournal.uin-suska.ac.id/index.php/sitekin/article/download/1604/1412

[10] Hadi, A.P., Sulistyowati, Santoso, R., 2017, "Analisis Pengaruh Kualitas Website Terhadap Kepuasan Pengguna Berdasarkan Metode WebQual 4.0 Pada Website Kemahasiswaan Institut Bisnis dan Informatika STIKOM Surabaya”, JSIKA Volume 6 Nomor $7 \quad$ ISSN : $2338-137 X, \quad$ available : http://download.garuda.ristekdikti.go.id/article.php?article $=882177 \& \mathrm{val}=5494 \&$ title $=\mathrm{A}$ nalisis\%20Pengaruh\%20Kualitas\%20Website\%20Terhadap\%20Kepuasan\%20Penggun a\%20Berdasarkan\%20Metode\%20WebQual\%204.0\%20Pada\%20Website\%20Kemahas iswaan\%20Institut\%20Bisnis\%20Dan\%20Informatika\%20Stikom\%20Surabaya 